\title{
The Impact of Strategic Orientation on Intellectual Capital Investments in Customer Service Firms
}

\author{
Kate Walsh, Cornell University \\ Cathy A. Enz, Cornell University \\ Linda Canina, Cornell University
}

This study examines the influence of intellectual capital on performance in customer service firms pursuing different strategic orientations (e.g., low-cost leader, differentiation). Grounding these arguments in the resource-based view and using 538 hotels in the lodging industry, this article employs an economic-based production model to empirically explore the performance effects of investing in three different types of intellectual capital: systems capital (operational knowledge), customer capital (brand and marketing knowledge), and human capital (knowledge from both service and professional employees). In addition, the authors account for key controls, including the physical asset, cost of living, customer demand, market segment, and company affiliation. Results reveal that for firms pursuing a differentiation strategy only, investments in both service employees and professional employees enhance performance. However, investments in systems capital and customer capital enhance performance for all the firms studied. The authors discuss the implications of this study for research in the services arena.

Investing in intellectual capital is crucial to ensuring that firms know how to execute operational strategies that enhance performance (Riahi-Belkaoui 2003). Yet spending on knowledge is especially challenging in customer service firms, such as retail outlets, restaurants, and hotels, that deliver products through high-volume, low- margin, intangible experiences created between low- skilled employees and customers (Bowen and Schneider 1988, Zeithaml, Parasuraman, and Berry 1985). Many of these firms sell a basic product through the creation of uniform and expeditious service exchanges provided by interchangeable employees (Gutek 1995; Oliva and Sterman 2001), whereas others offer specialty products with higher margins but rely on the same labor pool for the exchange. These firm types operate using different generic strategic orientations, originally identified by Porter (1985) as low- 
cost leadership and differentiation. While recognizing that a variety of specific strategies exist within these broad orientations (Campbell-Hunt 2000) and acknowledging that individual business strategies are as varied as the organizations that create them, the use of Porter's generic types can help us understand the role of the strategic context for resource allocations, especially expenditures on knowledge, in customer service firms. In this article, we focus on how investments in different components of intellectual capital shape performance for customer service firms who adopt different generic strategic orientations.

The authors gratefully acknowledge the assistance of Pannell, Kerr Foster, and the Center for Hospitality Research in providing access to the comprehensive lodging performance database used in this study. No individual hotel or chain identity was revealed to the researchers, and all information shared with Cornell University researchers is bound by agreements of nondisclosure and confidentiality. Only aggregate data will be provided in this report. All authors contributed equally to this research project.

The resource-based theory of the firm argues that organizational success can be explained in terms of the assets possessed by the firm (Penrose 1959; Rumelt 1984). That is, the most successful firms will be those who have a bundle of assets, both tangible and intangible, that are aligned with and support the strategy of the firm. A key intangible asset thought to deliver higher performance is intellectual capital, defined as the knowledge- based equity of a firm (Dzinkowski 2000). Recent scholars have gone so far as to argue that intellectual capital is more likely than other tangible and intangible resources to act as a source of competitive advantage (Bonds and Fitz-enz 2002; Hitt et al. 2001; Ng 2006; Swart 2006). We build from recent work in the resource- based theory of the firm to argue that, depending on a firm's strategic orientation, three key types of intellectual capital investments have the potential to differentially affect profitability. ${ }^{1}$ While it has been suggested that investments in intangible resources, and specifically intellectual capital, are crucial to service businesses (i.e., Bontis and Fitz-enz 2002; Namasivayam and Denizci 2006), there is still no clear grasp of how different components of intellectual capital shape performance, especially when customer service firms operate from different strategic orientations.

Most of the existing research arguing for the criticality of intellectual capital has concentrated on knowledge- intensive service firms, such as financial services, accounting, and law firms, that employ highly trained professionals (i.e., Andreissen 2005; Goldstein and Ward 2004; Hitt et al. 2001; Nachum 1999; Ng 2006; Wang 2005). However, the bulk of customer service firms sell experiences provided by low-wage service employees, in cooperation with the knowledge of their managers, and external sources of knowledge (e.g., management companies and franchisors). As a result of this preference in 
the literature, much remains to be understood about the value associated with customer service firms' knowledge- based investments. It is thus challenging for decision makers to effectively understand how the types of intellectual capital examined in this study, including service employees, service professionals, outside management companies, and franchisors, shape firm advantage (Kamath 2007; Stewart 1997). Yet knowing how expenditures on intellectual capital contribute to profitability is essential to any firm, and particularly customer service firms, whose core products are experience goods created through these intangible elements (Namasivayam and Denizci 2006; Ng 2006).

Recent work in the marketing arena highlights the importance of intangible assets as sources of advantage. Srivastava, Shervani, and Fahey $(1998,1999)$, for example, offered a framework examining the value and associated return of market-oriented intangible assets, such as brand equity and customer relationships. This emerging cross-functional view of core processes is part of marketing's larger paradigm shift, which recognizes that traditional measures of marketing-based productivity missed the ways these knowledge-based intangible assets contribute to shareholder value. Indeed, as Vargo and Lusch (2004) argue, intangible resources represent value- creating lever points crucial to firms whose service provision, rather than goods, is key to strong performance.

In this article, we first present our theoretical arguments and hypotheses; conceptually, we combine insights from the resource-based view of the firm, derived from strategic management theorists, with production-function framework anchored in microeconomic theory. Next, using financial data from a sample of individual hotel properties in the lodging industry located throughout the United States, we empirically test the impact of intellectual capital investments on individual hotel-level performance. ${ }^{2}$ We employ a production-function model in which output is related to both the tangible and intangible factors of production (B. Hall 1993; Lev and Sougiannis 1996). This framework is used extensively in accounting, economics, and finance for studying the productivity of inputs such as capital, labor, energy, and research and development (Berndt and Morrison 1995; Chan, Lakonishok, and Sougiannis 2001; Kothari, Laguerre, and Leone 2002). A review of accounting studies using this framework, for example, revealed that the relationship between inputs and earnings is positive and, furthermore, that the specific inputs add value beyond that of generating contemporaneous sales (Lev and Sougiannis 1996). After discussing this framework and the results in greater detail, we review the implications of our findings for understanding the performance impact of intellectual capital investments in customer service firms. 


\section{Theoretical Background}

The theoretical foundation of this study is grounded in the resource-based view of the firm, which contends that resources are strategic assets that play a central role in creating a sustained competitive advantage (Barney 1991; Penrose 1959; Peteraf 1993; Wernerfelt 1984). Resources act as "isolating mechanisms" in that they generate an advantage that competitors find difficult to replicate (Rumelt 1984). Consistent choices about investments in valuable and rare resources, as well as ways to allocate and coordinate the distinctive capabilities they create, shape firm heterogeneity and enable firms to realize above-normal rents or rates of return (Amit and Shoemaker 1993; Barney 1991; Lippman and Rumelt 2003; Oliver 1997; Peteraf 1993). Put simply, "the resource-based view addresses the fit between what a firm has the ability to do, and what it has the opportunity to do" (Russo and Fouts 1997, p. 536).

While resources that generate advantage can include both tangible and intangible assets, recent work argues that, in today's economy, intangible assets have the greater potential to create firm capabilities that lead to advantage (Carmeli and Tishler 2004; Hitt et al. 2001; Teece, Pisano, and Shuen 1997). Indeed, one of the more valuing- enhancing forms of intangibles is a firm's knowledge-based resources or its investments in its intellectual capital (Decarolis and Deeds 1999; Ethiraj et al. 2005; Haas and Hansen 2005; Riahi-Belkaoui 2003; Teece et al. 1997). Also referred to as operant resources, or resources that are used to act on other resources in ways that produce multiplicative effects (Constantin and Lusch 1994; Vargo and Lusch 2004), a firm's intellectual capital has the potential to produce unique firm-based capabilities. Because it is capable of many simultaneous applications, cannot be depleted with use, and is socially complex, intellectual-based knowledge provides firms with broad- based value that is difficult for competitors to replicate (Hitt et al. 2001; King and Zeithaml 2003). For example, McEvily and Chakravarthy's (2002) recent study found that the complex and tacit nature of technology firms' knowledge base offers protection against imitation and strengthens its inventive capabilities. So too, Wiklund and Shepherd's (2003) study revealed that knowledge- based resources influence a firm's entrepreneurial orientation and ultimately performance. These findings suggest that the value of an enterprise is a function of its investment in its intellectual capital (i.e., Carmeli and Tishler 2004; R. Hall 1992, 1993; Mahoney and Pandian 1992). In fact, it has been argued that a firm's intellectual base approximates $85 \%$ of its total economic value (Smith and Parr 2000). Researchers have concluded that a firm's intellectual capital is more likely than other resources to act as a source of advantage (Bonds and 
Fitz-enz 2002; Sherer 1995; Wernerfelt 1984) and may possibly be the most important source of sustained competitiveness (Spender and Grant 1996).

The idea that investments in intellectual capital are important has been a prominent theme throughout the services literature. For example, abundant research exists suggesting that a firm's brand adds value (Ambler et al. 2002; Hogan, Lemon, and Rust 2002). In fact, a line of inquiry in marketing specifically examines the concept of brand equity, which refers to the added value a brand brings to a firm's marketing efforts (Keller 1993). So too, the seminal research on service quality conducted by Parasuraman, Zeithaml, and Berry $(1985,1988)$, further developed by Bitner, Booms, and Tetreault (1990) among others, and later refined by Zeithaml, Berry, and Parasuraman $(1993,1996)$ and Zeithaml (2000) links the service experience, and the employees that provide this experience, with customer expectations, their repurchase intentions, and firm profits. In fact, it has been argued that employees play an important role in guiding customers through the service-delivery experience by displaying responsiveness, empathy, and assurance; these behaviors represent key components of the service quality model (Siehl, Bowen, and Pearson 1992). In addition, some researchers (i.e., Gittell 2002; Mills and Ungson 2001) also examine how employees affect their organizations through the ways they serve one another. This body of work emphasizes that intangible assets, and in particular intellectual-based knowledge, are crucial to the success of any service firm. Indeed, a recent study argues that it is possible and useful to link customers' lifetime value, as a type of intangible asset, to a firm's financial performance, a concept with which resource-based theorists would likely agree (Hogan, Lehmann, et al. 2002).

\section{Intellectual Capital and Strategic Orientations}

While the broad contention that intellectual capital is valuable can be found throughout the literature, the field is less clear on how different types of intellectual capital create performance advantage (Bontis and Fitz-enz 2002). Certainly not all resources are equal in their ability to help an organization achieve high levels of performance, especially taking into consideration a firm's strategic context. Overall, we argue that performance can be enhanced through investments in the three different types of intellectual capital discussed next and that the degree to which increasing investments in these types of knowledge contributes to performance depends on the strategic orientation of the firm.

The literature on intellectual capital has deployed a variety of different classification schemes (i.e., Edvinsson and Malone 1997; Petrash 1996). We adopt the widely accepted, three-category 
classification, which divides intellectual capital into codified knowledge about an organization's systems and operations (systems capital); knowledge about customers, markets, and distribution (customer capital); and knowledge acquired from people skills and expertise (human capital; Bontis 1996; Bontis and Fitz-enz 2002; Stewart 1997; Sveiby 1997). Figure 1 provides an overview of the three types of intellectual capital used in this study. Whether professional based or customer based, it is common practice for service firms to purchase some of their intellectual capital from external consultants and franchisors. Thus, as noted in Figure 1, in this study, both systems capital and customer capital are purchased under contractual and fee- based arrangements from external knowledge providers and imported into the organization (Namasivayam and Denizci 2006). Indeed, what makes the current study important for understanding intellectual capital in customer service firms is that all of the firms examined relied on external sources to obtain these types of intellectual capital. Alternatively, human capital is derived from the skills and expertise of internal professional and frontline service workers; Figure 1 uses a traditional organizational pyramid to show how human capital comes from lower level service employees and higher level professionals. Applying this classification, we discuss each type of intellectual capital in turn.

FIGURE 1

Types of Intellectual Capital

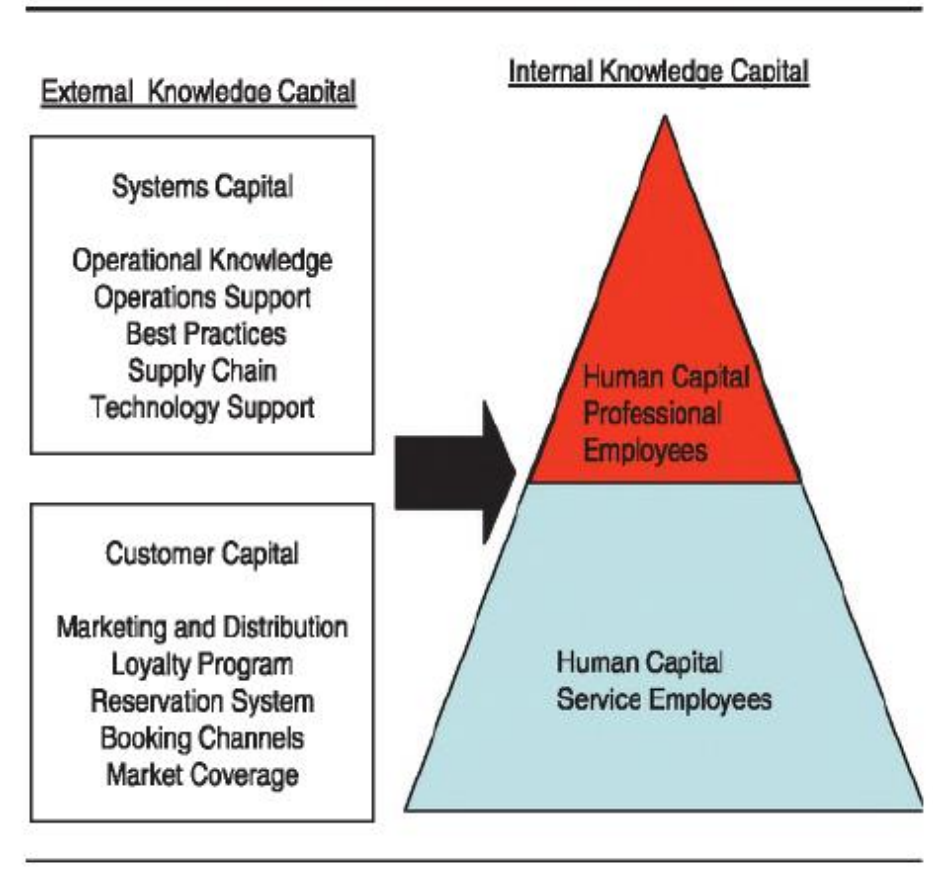




\section{Systems Capital}

In customer service firms, systems capital refers to operational knowledge about how to organize and direct employees to deliver a service product to a customer base (Bonds 1998). Systems capital, also termed operational capital or structural capital (Riahi-Belkaoui 2003; Seetharaman, Sooria, and Saravanan 2002; Swart 2006), represents all nonhuman stocks of codified knowledge in organizations, including a firm's policies, management procedures, and organizational systems and structures (Engstrom, Westnes, and Westnes 2003). Roos et al. (1997) refer to systems capital as what remains in the company when the employees leave for the night. Because systems capital represents the ability to apply human capital to a service exchange (Seetharaman et al. 2002), it is often viewed as a critical type of intellectual capital. That is, if a firm has poor systems and structures, it cannot organize its workforce to deliver its product, and it will fail to realize the potential return from investments in all forms of intellectual capital (Bonds 1998).

While firms can develop this type of capital in-house, as mentioned, it is a common strategy for customer service firms to directly access and import systems capital into the organization through contracting with external knowledge providers, or management firms (Fulop and Forward 1997). For a fee, these external companies provide firms with critical best-practice operational support information, as well as continued consultation on ways firms can design and leverage their systems through strategic capital improvements (Fulop and Forward 1997). For example, hotel management companies typically provide individual hotels with models for creating and sustaining systems such as service-delivery processes, policies, and procedures; technological support; and supply chain management and procurement. In addition to obtaining knowledge about a proven business model and lowering their start-up risk, firms purchasing systems capital benefit from the economies of scale that can only be realized by purchasing the services of larger organizations (Inma 2005; Shane 1998). Indeed, as noted in the literature, these types of arrangements enable firms to acquire intellectual capital at a lower cost than if they developed the capital internally and independently (Teece 2000).

An example of a provider for the lodging industry is Interstate Hotels \& Resorts, a hotel management company that has been offering systems capital to the owners of 200 hotels for more than 45 years. Interstate's knowledge resources include systemized programs in the following areas: rooms operations, food and beverage operations, finance, human resources, procurement, risk management, concept development, construction, information technology and support, and legal services. Firms that purchase Interstate's services gain access to their proprietary operational systems, management expertise, and scale economies derived from their volume of business. 


\section{Customer Capital}

Customer capital is considered a market-based asset that is obtained through affiliation with a brand and its reputation. Market-based assets are said to "arise from the comingling of the firm with entities in the external environment" (Srivastava et al. 1998, p. 2), and they consist of knowledge about markets, distribution channels, and what it takes to attract and retain loyal customers. When a firm purchases customer capital from an external organization, they gain access to that company's brand, including its associated customer databases, marketing and distribution outlets, advertising initiatives, reservation and booking systems and its customer-loyalty programs, all forms of knowledge related to marketing conditions and channels, and a firm's relationship with its customers (Bontis, Keow, and Richardson 2000; Srivastava et al. 1998).

The brand name itself is often viewed as the most common element of customer capital (Brooking 1996). Brand refers to "a name, term, sign, symbol or design ... which is intended to identify the goods and services of one seller or group of sellers" (Kotler 1991, p. 442). Through the images it conveys and the awareness it triggers in customers' minds, brand recognition is a key method for both attracting new customers and retaining current ones (Keller 1993). Brand cues customers that they can trust the product for sale, and it reduces their time and search costs (Washburn, Till, and Priluck 2004; Zeithaml 1988). For example, the Four Seasons hotel brand and the Economy Inn brand convey messages to customers that support and clarify the different strategic orientations of these companies. Brand also affects customers' price-sensitivity points and repurchase decisions and ultimately a firm's revenues and equity value (V. Lane and Jacobson 1995; Srivastava et al. 1998). When customer service firms purchase access to customer capital, they obtain an immediate reputation that can be used to attract a revenue base.

To illustrate, a hotel can contract to put the Marriott brand on its property. When it does, it purchases access to Marriott's extensive customer reservation systems, as well as its customerrelationship management, advertising, and marketing programs. Marriott also requires its participating hotels to comply with standards of quality to ensure that the product remains consistent from property to property. Thus, participating hotels benefit from the immediate recognition that the Marriott logo provides. In addition, Marriott customers generally arrive with consistent and reasonable expectations of the quality of the physical product, as well as the service experience associated with purchasing this product. All of the individual hotels in this study were affiliated with a brand. 


\section{Human Capital}

Human capital represents the knowledge, skills, and experience of firm employees. Similar to research in human resource architecture (i.e., Lepak and Snell 1999, 2002), different employee groups provide unique components of human capital and bring differential value to their organizations. In customer service firms, two sources of human capital or employee groups have the potential to offer a benefit: service employees and professional employees. Service employees are the frontline employees who engage with the customer and deliver the product, as well as the behind-the-scenes support employees who ensure the operation is running seamlessly. These employees execute the firm's strategy. This type of human capital, such as a restaurant waiter or a hotel front desk clerk, for example, is thought of as easy to obtain in the labor market. Alternatively, professional employees represent the more sophisticated intellectual base of the organization, and their knowledge and skills are thought of as more rare and difficult to acquire. Individuals who fall into this employee category, such as a controller or human resources director, for example, bring with them more formalized education and training. In orchestrating the combination of service encounters that compose an overall service experience, these employees shape the firm's strategy and ensure its flawless execution.

The value associated with a firm's human capital groups has been the focus of much debate. Because human capital is typically developed within the firm, it is usually the source of tacit, socially complex, firm-specific knowledge, which is considered more valuable and rare than general, articulable forms of knowledge (P. J. Lane and Lubatkin 1998; Mowery, Oxley, and Silverman 1996; Swart 2006). In fact, of the three asset groups that compose intellectual capital, specifically systems capital, customer capital, and human capital, human capital is considered the most complex, making it more difficult to imitate or substitute and hence a more sustainable source of competitive advantage (Barney 1991; Black and Boal 1994; Hitt et al. 2001; Peteraf 1993).

Yet while conceptually viewed as valuable, the specific return on investments in human capital is poorly understood, especially for customer service firms that hire low-skilled employees at a living- or minimum-wage salary. Generally, the knowledge held by low-skilled workers does not require individuals to invest in education beyond a basic reading/writing level and is viewed as common and readily available. In the context of competitive advantage, this type of knowledge would be easy to imitate and substitute. Thus, at first glance, many forms of human capital in typical customer service firms are considered inexpensive to obtain and easy to replace and thus are not traditionally viewed as leveragable investments (Lepak and Snell 1999, 2002). Rather, low-skilled employees have often been 
considered necessary for doing business, and their wages have been regarded by practicing managers as expenses to be minimized.

This managerial orientation has been articulated fully in the research in human resource accounting (i.e., Flamholtz 1985; Flamholtz, Bullen, and Hua 2002; Flamholtz and Lacey 1981; Sackmann, Flamholtz, and Bullen 1989), which observes that investments in low-skilled human capital are treated as current-period expenses in the financial records of most organizations. Because the investment in human capital is not recorded on the balance sheet as an asset, its rate of return is often implicitly assumed to be zero at most. As such, low-skilled labor is often not considered a source of competitive advantage, and it is common for decision makers to minimize the cost of service delivery by making a modest and normative investment in employees.

We question this assumption and argue that the investment in human capital, for not just professional workers but specifically for low-skilled employees, in addition to investments in systems capital and customer capital, can enhance a firm's profitability; yet the relative impact of each type of intellectual capital on performance will depend on a firm's strategic orientation. If a firm seeks operating efficiency and a standardized product, then the employee may be simply a hired hand; alternatively, a differentiated focus may require a hired mind in which a firm spends more to obtain more. Next, we turn to a discussion of these strategic orientations.

\section{Strategic Orientations}

The choice of intellectual capital investments that yield the highest profit should depend on whether customer service firms choose to be low-cost leaders or alternatively, differentiators, as the products provided and hence resources associated with each of these two strategic orientations differ. The first strategic orientation, low- cost leadership, involves offering a basic product through creating a production system more efficient than the competition's. The second strategic orientation, differentiation, entails creating a unique product or service for which firms can charge a price premium (Porter 1985). Competitive or business-level strategy defines an organization's approach to competing in its chosen markets. According to Porter (1985), firms create superior value for customers by either offering a basic product or service that is produced at the lowest possible cost or a preferred product or service at a somewhat higher price, where the price premium exceeds the additional cost of creating it.

While widespread acceptance of Porter's (1985) scheme as a dominant paradigm in competitive strategy exists, a recent meta-analysis found that cost and differentiation play a "high-level" role in discriminating between possible competitive strategies and may fail to provide universal explanations 
(Campbell-Hunt 2000). In keeping with these findings and others that report customization and standardization tradeoffs are more likely for services than goods (Anderson, Fornell, and Rust 1997), we use the two strategic orientations from an empiricists versus taxonomic perspective in which we do not impose an ex ante requirement that cost and differentiation be high-level discriminators. Rather, these orientations are a point of focus for our investigation into intellectual capital, as reflected in the following hypotheses.

FIGURE 2

The Impact of Intellectual Capital on Firm Performance in Different Strategic Contexts

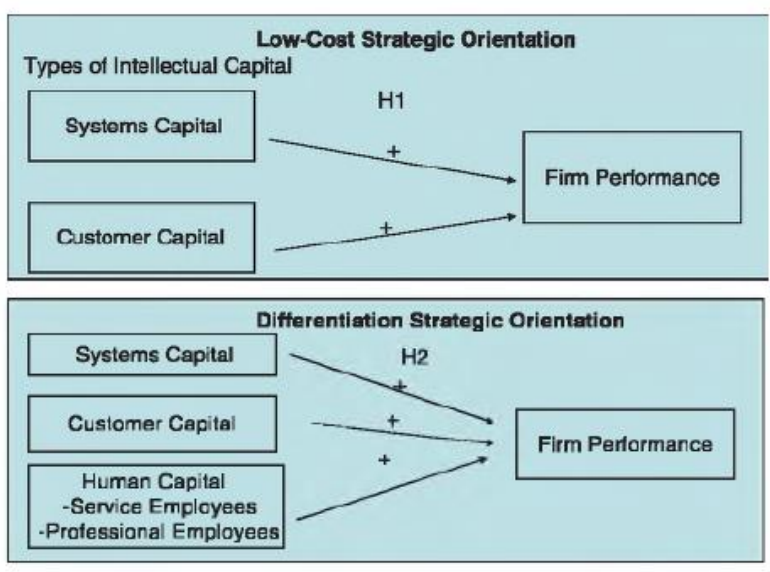

\section{Hypotheses}

Different strategic orientations require different types and levels of resource allocation to achieve superior performance, and as a result, the bundle of performance-enhancing resources should vary. The underlying rationale for our argument is that because expenditures reflect value, it is likely that if intellectual capital is a value-enhancing investment, it will create additional value beyond its cost. As a result, when a firm makes greater expenditures on the various types of value-enhancing intellectual capital, profits (which are net of costs) will rise. However, a firm's decision to operate through cost leadership or, alternatively, differentiate itself with a unique service, will lead to different investments in the key types of intellectual capital. We develop two hypotheses that reflect this overall assumption. The first examines the impact of intellectual capital investments for low-cost leaders, and the second considers the same relationship for firms that differentiate. The hypothesized relationships are depicted in Figure 2, which outlines our predictions for firms that operate under each of the two strategic orientations. 


\section{Intellectual Capital Investments for Low-Cost Leaders}

Firms who strive to be low-cost leaders compete by creating operating efficiencies relative to their competitors' (Porter 1985). These firms attract their customer base by setting low price points, and in return, they offer customers a standardized product. The strategy for low-cost leaders is to create these efficiencies through obtaining boiler-plate operational knowledge. Specifically, when low-cost leaders purchase the expertise of outside sources, they are likely to benefit from obtaining access to economies of scale from volume purchasing, economies of learning via improved organizational routines and frameworks, and efficient service design through process innovations (Grant 2008). They may acquire these benefits at prices that allow them to minimize the costs of service delivery, while still providing a basic product to customers. In addition, low-cost leaders that purchase customer capital obtain immediate access to a customer database, as well as the ability to reach potential customers through advertising and distribution. While these types of capital are frequently generic or universal in that they are easily obtained from third-party organizations (i.e., management companies and franchisors), their purchase can yield above-average returns.

We argue that both systems capital and customer capital purchased from outside vendors are relatively more important to low-cost leaders than developing human capital. This is because customers purchasing from a low-cost leader expect a basic, no-frills product. The knowledge provided by these management companies and franchisors would be sufficient in providing customers with a rudimentary product that meets the service and quality standards that they expect from a brand. As a result, while staffing a basic group of employees would be necessary to run low-cost leader businesses, these firms would not realize supplemental profits from increasing their expenditures on labor and there would be no need to incur additional investments in service employees, beyond operational necessity. So too, investing in professionals would be an expensive and possibly redundant form of human capital for lowcost leadership firms. This is because these firms require less customized knowledge and unique expertise to standardize their service product. Furthermore, these firms purchase the managerial expertise embedded in the service frameworks and distribution networks provided by outside sources of systems capital and customer capital. Thus, to effectively execute their strategy and achieve higher performance, the most profitable of these firms would make fewer additional investments in their employees beyond that required to provide the basic service for sale.

Based on these arguments, we would expect that for customer service firms that pursue a lowcost leadership strategy, the wisest choices in intellectual capital center on purchasing boiler-plate forms of systems capital, as well as access to a customer base and reputation through brand. These 
types of capital enable these firms to provide a recognizable and affordable product to the specific customer base targeted by their chosen brand. We would also expect that additional investments in service and professional human capital within the firm, beyond that required to provide a basic service, would be inefficient and have no effect on performance. As a result, we would argue that customer service firms that pursue a low-cost leadership strategy benefit when they make greater investments in two of the key components of intellectual capital: systems capital and customer capital. Stated more formally:

Hypothesis 1: In customer service firms that pursue a strategic orientation of low-cost leadership, greater investments in systems capital and customer capital will yield higher firm performance.

Intellectual Capital Investments for Differentiators

The goal of customer service firms that pursue a differentiation strategy is to provide a unique product at a price premium to a clearly defined and targeted customer (Porter 1985). This strategic orientation entails building elements of difference in the product through creating a responsive, customer-focused service delivery system. Higher costs associated with such a strategy are more than offset by the prices loyal, repeat customers are willing to pay for the service. As with the low-cost leaders, we would expect that systems capital and customer capital would be important to firm performance. These types of capital would enable a firm to attract a customer base and provide this base with a personalized service experience. In this case, though, systems capital would also provide the operational foundation for orchestrating a series of seamless, customized services. Customer capital would provide the image, customer databases, and distribution channels that would enable a differentiated firm to attract and retain a loyal following willing to pay a premium price for a higher quality product. While customer capital would be important to establish reliability for a low-cost provider, it would serve to convey identity and embody a lifestyle for leading differentiators (Grant 2008). Thus, expenditures on customer capital would likely help differentiators to influence and reinforce customer perceptions.

In addition, we would expect that customer service firms that pursue a differentiation strategy would create unique differences and enhanced performance through greater investments in their service employees. The essence of a highly differentiated service organization is expressed in the way employees execute the firm's strategy when delivering the service experience to customers. By offering specialized services and thoughtful, unique encounters, these firms can personalize their services and create longer term relationships so crucial to developing a loyal customer base that has the highest 
profit potential to the firm (Reichheld 1996; Reinartz and Kumar 2000, 2002; Rust and Zahorik 1993; Vavra 1992; Zeithaml et al. 2006). Thus, an important source of human capital would be the service employees who provide the necessary skills and tacit knowledge to deliver quality service (Bowen and Lawler 1992, 1995). Social, emotional, and aesthetic factors that shape customer choice and a willingness to pay a premium are apt to occur in the encounter (Weigelt and Camerer 1988). While brand and operating standards may convey status and exclusivity, the service provider is key to meeting the complex needs of a differentiated firm's customer base (Bowen and Lawler 1992), especially because these needs are more likely to be unexpressed, abstract in concept, and diverse in nature.

We would also expect that professional employees would be important in designing the unique, highly differentiated service experiences produced and supported inside the firm. Professionals would be responsible for implementing the firm's overall positioning strategy, and their presence would help create firm distinction through ensuring that service employees are allocated resources that enable them to deliver on the complex service concept. Because a differentiated strategy requires a firm to position itself based on its unique product characteristics, professional employees would be essential to aligning and integrating the complex knowledge system derived from investments in from systems capital, customer capital, and service employees. Based on these arguments, we would hypothesize the following:

Hypothesis 2: In customer service firms that pursue a strategic orientation of differentiation, greater investments in systems capital, customer capital, and both sources of human capital (service employees and professional employees) will yield higher firm performance.

\section{Method}

The main objective of this study is to examine the impact of key types of intellectual capital investments on performance for customer service firms that adopt different strategic orientations. We do so through testing the effects over time of intellectual capital expenditures on net operating income for a large cross-section of individual hotels or lodging properties. The lodging industry was selected as the setting for this study because it offers an opportunity to explore the importance of the three types of intellectual capital investments identified in the literature as relevant for service firms. In addition, each property follows the uniform systems of accounts for hotels, making it possible to obtain an identical detailed breakdown of expenses by department across all individual hotels in the sample. This enabled us to isolate the allocation of resources across the various forms of inputs. Last, the lodging industry is a large and relevant sector of customer service firms. An exploration of the impact of 
investments in intellectual capital in this sector has the potential to offer greater performance insight to a substantial number of U.S. service businesses that employ low-skilled workers.

\section{Data Source}

Annual income statement data for the sample of hotels used in this study were obtained from PKF Hospitality Research Consulting for the 1998-2001 period. PKF Hospitality Research Consulting is an independent research branch of a firm that tracks hotel financial and operating performance at the individual property level. The sample consisted of 538 franchised hotels from 45 states in the United States; each hotel obtained its systems capital and its customer capital from outside sources. Four different market segments were represented in the data sample. Sixty-nine hotels were economy, 204 were midscale, 158 were upscale, and 107 were luxury. The sample hotels were examined during a 4year period in which each hotel's yearly performance was counted as a unit of observation. As noted, these annual data are particularly valuable because they were consistently gathered and standardized to facilitate across-organization comparisons on key income and expense categories. All dollardenominated variables were converted to 2001 constant dollars using the Consumer Price Index (CPI) by year, supplied by the U.S. Bureau of Labor Statistics.

Note that some hotels in the PKF database did not contribute their data until after 1998, and as a result, less than 4 years of data were available for every hotel in the sample. However, comparing the summary statistics on the key variables for the subsample of hotels with 4 years of data to the subsample of properties with less than 4 years of available data revealed no systematic differences. In addition, the estimation technique employed in this study (discussed in the following sections) allowed for unbalanced data. Thus, because the unbalanced data did not present estimation problems and to avoid sample bias, all properties were included in the analysis. The sample consisted of 764 property years of data, representing 273 different hotel properties that adopted a low-cost strategic orientation, and 819 property-years of data, representing 265 different hotel properties that adopted a differentiation strategic orientation.

\section{Empirical Model}

To test the hypotheses, a standard productivity measurement approach was used (Brynjolfsson and Hitt 2003). The production function relates output to labor and material inputs, as well as to the stocks of physical and intangible capital (B. Hall 1993; Mairesse and Sassenou 1991). Consistent with Lev and Sougiannis (1996), net operating income of each individual hotel was defined as a contemporaneous function of the total assets of the hotel property. We categorized total assets as 
tangible assets, namely the market value of the physical asset, and intangible assets or intellectual capital. The estimated equation is as follows:

$N O I_{i, t}=f\left(P A_{i, t}, I C_{i, t}\right)$

where $\mathrm{NOI}_{i, t}$ is net operating income for hotel property $i$ at time $t, P A_{i, t}$ is the value of the tangible (physical) assets for hotel property $i$ at time $t$, and $I C_{i, t}$ is the value of the intangible (intellectual capital) assets for hotel property $i$ at time $t$.

\section{Measured Variables}

To operationalize the estimation of this equation, four measures of intellectual capital were applied. These measures were complemented with numerous control variables devised to control for environmental conditions and tangible asset investments. In addition, because this study examined hotels of various sizes (i.e., number of rooms available in the property) and a positive relationship likely exists between size and earnings, all hotel property- specific variables, including all independent and the dependent variables, were scaled by the annual number of rooms available for sale in each hotel.

Firm performance. Firm performance, the dependent variable in the model, was measured by using annual operating income before interest expense, depreciation, and taxes per room available for sale (Lev and Sougiannis 1996). Operating income before these three deductions is widely viewed by service industry analysts, researchers, and practitioners as the predominant measure of performance (Schmidgall 1999).

Types of intellectual capital. Intellectual capital was categorized into four measures, defined by the expenditures associated with investing in systems capital, customer capital, and two types of human capital. Human capital investments were divided into those for service employees and those for professional employees. Following Lev and Sougiannis (1996), expenditures on each of the intangible factors were used as proxies for their value.

Systems capital was measured by using the annual base and incentive management fee each hotel pays to an external management company for establishing and maintaining all operational systems, policies, and procedures. Customer capital was measured as the annual fee hotels pay to external brand franchisors, as well as all advertising, marketing, and selling expenses. Note that all hotels in the study employed a management company and affiliated with a brand. As a result, we were able to examine the impact of systems capital and customer capital when purchased from outside sources. In addition, it is important to note that a hotel company, such as Hilton, could act as both the management company providing systems capital and the franchisor providing customer capital to one 
hotel. In these cases, the income statement treats the expenditures related to each form of service as separate line items, so issues of confounding were not of concern. (We also controlled for corporate affiliation, discussed in the next section.) It could also be the case that a hotel's provider of systems capital is an independent management firm distinct from the brand company that provides its customer capital. In either case, investments in systems capital and customer capital were not comingled in the database.

Human capital in customer service firms is primarily an investment in employee wages and salaries. In this study, the two human capital measures of service employees and professional employees were derived from the total annual wages and salaries, including benefits, for these employee groups. Service employees were those working in revenue-generating departments, including the front desk and restaurant operations, as well as those working in non-income-producing departments, such as maintenance and laundry. Professional employees included those in accounting, marketing, and human resources, along with senior management.

Environmental and tangible asset controls. Because a variety of environmental conditions can shape firm performance, both local economic and competitive factors were controlled. These included the following: the cost of living, local market demand for lodging, the market segment of each hotel, and the corporate affiliation of each hotel's provider of systems capital and customer capital.

Local economic factors such as the variation in the cost of living and market demand for hotel products can make it difficult to compare hotels in different geographic locations. Furthermore, the measure of human capital investment (i.e., employee wages and salaries) might be unduly influenced by variations in the cost of living from one location to another. Hence, we controlled for the cost of living by calculating a cost of living index for each hotel via zip code using the CPI, obtained from the U.S. Bureau of Labor Statistics. In addition, while hotels in some geographic locations may have higher demand and fill their rooms, others could be half-empty because of local market demand conditions. To control for differences in market demand across geographic locations, a variable was devised that captures local demand by calculating the average annual local occupancy rates for hotels in each zip code in which the sample hotels operated.

The lodging industry has a fairly well-defined system of segmentation. For example, a luxury hotel does not as a rule directly compete with a midscale hotel. However, to control for the impact of market segmentation on hotel performance, dummy variables were created that placed each hotel into its market segment, as defined by the hotel classification system widely used throughout the industry and provided by our data source. 
Another important competitive factor that can shape a hotel's performance is the specific company it selects to purchase its systems capital or customer capital. An examination of the data revealed 55 different providers of systems capital and 23 different providers of customer capital. We controlled for these corporate affiliation effects by including a series of dummy variables in each of our strategic orientation models.

In addition, because the data are both time series (1998-2001) and cross-sectional (hotel properties), a trend measure was devised to control for year-specific heterogeneity. Specifically, we created dummy variables for each year over the period from 1998 to 2001.

Finally, for hotels, the most critical tangible asset is the hotel itself or, more precisely, the market value of the physical asset. In the lodging segment, at the property level, tangible assets usually only include the physical assets. In general, financial assets also generate income; however, at the hotel or business level, the financial assets, namely cash and accounts receivable, are negligible, as industry practice is to realize zero year-end balances in these accounts. As a result, financial assets were not included as a productive input. To meaningfully examine the effects of intellectual capital on firm performance, we needed to control for this primary tangible asset and did so by estimating the current market value of a hotel's property. Specifically, to approximate each hotel's current assessed value for its building and land, we divided the hotel's annual property tax payment by the appropriate state tax rate in which the hotel operates.

While the number of employees would have been a desirable control variable, these data were not available. However, we believe that the effort to scale all of the variables (except occupancy) by the number of hotel rooms (i.e., size) helps to assure that the models are appropriately specified. It is a reasonable assumption that the number of employees varies as a linear function of the size of the hotel, and thus by scaling the variables by size and including measures of the physical asset and environmental influences, concerns associated with the inability to obtain data on the number of employees for the analyses have been addressed.

\section{Strategic Orientations}

The strategic orientation of each hotel, either low-cost leadership or differentiation, was determined by the hotel property's classification as a limited-service or full- service hotel. Limitedservice hotels distinguish themselves through their price. These properties tend to offer a basic product (i.e., room) with limited onsite food and beverages. Other services are rarely included in the product. Economy and midscale segments fall into this category. Alternatively, full-service hotels, including 
upscale and luxury hotels, offer complete on-site food and beverage and distinguish themselves through their services, facilities, and amenities. These enterprises also tend to offer services such as a fitness center, gift shop, and business center. Our sample included 273 hotels that distinguished themselves as limited service (pursuing a low-cost leadership strategic orientation) and 265 properties that distinguished themselves as full-service (pursuing a differentiation strategic orientation). As noted earlier, the market segment controls enabled an accounting of product and quality variation that might exist within each strategic orientation.

\section{Analytic Technique}

Fixed-effects regression models, using a restricted maximum likelihood procedure, were used to test our hypotheses. A fixed-effects modeling approach was selected for this study because panel data (also known as pooled time-series and cross-sectional data) often have omitted factors that can cause correlation in the residuals. The data in this study comprise multiple observations for the same hotel property across time and multiple hotel properties contracting with the same management company or brand company. If we omitted a management company or brand company variable that explains a portion of the variability in performance across properties that is orthogonal to the other property-level independent variables, then this variability would be included in the variability of the disturbance term. As a result, the disturbance terms would be correlated. Accordingly, the management company and the brand company were included as fixed effects in the model. The fixed effects model was chosen over the random effects model based on the Hausman (1978) test and the Bayesian information criterion as tools in model selection (Rafferty 1995).

A restricted maximum likelihood procedure was used for estimation because the multiple observations per property would likely result in a nonspherical covariance matrix, hence violating a condition of ordinary least squares (OLS) regression. This computational procedure accounts for the dependence across observations within a cluster (Greene 2000). The variance/covariance matrix was estimated empirically to allow for dependent observations and to produce heteroskedasticity-consistent standard errors (White 1980). Because of the potential for nonspherical errors, the following empirical relationship was tested for each strategic-orientation subsample using restricted maximum likelihood (Greene 2000): 


$$
\begin{aligned}
& N O I_{i, t}=\alpha_{i}+\sum_{m=1}^{M_{n}-1} \beta_{1, m} M n g_{i, m}+\sum_{c=1}^{c_{n}-1} \beta_{2, c} C h n_{i, c}+\sum_{s=1}^{S_{o}-1} \beta_{3, s} S g m t_{i, s} \\
& +\sum_{y=1}^{3} \beta_{4, y} \text { Year }_{y}+\beta_{5} \operatorname{CoL}_{i, t}+\beta_{6} \text { Dmd }_{i t,}+\beta_{7} P A_{i, t}+\beta_{8} \operatorname{SysCap}_{i, t} \\
& +\beta_{9} \operatorname{CusCap}_{i, t}+\beta_{10} \operatorname{SerEmp}_{i, s}+\beta_{11} \operatorname{ProEmp}_{i, \mathrm{~s}}
\end{aligned}
$$

where $i$ is the index to an individual hotel property; $t$ is the index to the years 1998-2001; $O$ is the index to the two strategic orientation subsamples, low-cost leaders and differentiators; $m$ is the index to individual management company; $M_{0}$ is the number of different management companies in the strategic orientation $(O)$ subsample; $c$ is the index to individual chain or brand companies; $C O$ is the number of different chain companies in the strategic orientation $(O)$ subsample; $s$ is the index to market segment of the hotel property; $S_{0}$ is the number of different market segments in the strategic orientation $(O)$ subsample; $y$ is the index to the years 1999-2001; $\mathbf{M n g}_{m}$ is an indicator variable that takes the value 1 if the management company code is equal to the management index $(m)$ and 0 otherwise; $C h n_{c}$ is an indicator variable that takes the value 1 if the chain or brand company code is equal to the chain index (c) and 0 otherwise; $\mathrm{Sgmt}_{s}$ is an indicator variable that takes the value 1 if the market segment code is equal to the market segment index ( $s$ ) and 0 otherwise; Year $_{y}$ is an indicator variable that takes the value 1 if the year is equal to the year index (y) and 0 otherwise; NOli,t is net operating income in 2001 constant dollars for hotel $i$ at time $t$ scaled by the number of rooms; $C o L_{i, t}$ is a location-specific cost of living index control; $D m d i, t$ is a control variable in percent that represents the local market demand conditions within the same zip code of hotel $i$ at time $f ; P A_{i t}$ is the value of the physical assets in 2001 constant dollars for hotel $i$ at time $t$ scaled by the number of rooms; SysCap $i, t$ is the expenditure on management fees in 2001 constant dollars of hotel $i$ at time $t$ scaled by the number of rooms; CusCap $i, t$ is the expenditure on brand fees in 2001 constant dollars of hotel $i$ at time $t$ scaled by the number of rooms; SerEmp $p_{i, t}$ is the expenditure on service employees in 2001 constant dollars for hotel $i$ at time $t$ scaled by the number of rooms; and ProEmp $i, t$ is the expenditure on professional employees in 2001 constant dollars for hotel $i$ at time $t$ scaled by the number of rooms. 


\section{Results}

Descriptive statistics and correlation coefficients for the sample are presented in Tables 1 and 2, respectively. In Table 1 (for low-cost strategic orientation), note the high correlation of .82 between service and professional employees, and in Table 2 (for differentiation strategic orientation), note a similar high correlation of .73. An examination of the condition index and the variance inflation factors suggest these two factors may be causing a potential multicollinearity problem. According to Greene (2000), a condition index of 30 to 100 indicates moderate to strong collinearity. The condition index for service employees and professional employees was approximately 68 and 32, respectively, for the lowcost sample and 69 and 45 , respectively, for the differentiated sample. While multicollinearity is a potential problem in most empirical work, the important issue is whether the implications of the results change because of multicollinearity. Thus, we examined whether the exclusion of each of these two variables from the model affected the results. We found that the estimated parameters of the other variables in the equation did not change significantly when either service or professional employees were excluded from the equation. These results suggest that the high correlation between these two variables does not affect the results.

Table 3 shows the results of the analyses for firms pursuing both a low-cost leadership and differentiation strategic orientation. For both models, the cost of living and market demand control variables were positive and significant. The physical property asset did not have a statistically significant impact on performance for either strategic orientation.

In Hypothesis 1, we predicted that for firms that pursue a strategic orientation of low-cost leadership, greater investments in systems capital and customer capital will yield higher firm performance. We found support for this hypothesis. Both systems capital and customer capital coefficients were positive, indicating that for low-cost leaders, investments in these types of intellectual capital enhance profitability. More important, the relative magnitude of the system capital and customer capital coefficients ( 2.929 and 2.446 , respectively, both at $p<.001$ ) offers an indication of the impact that additional investments in these two external forms of knowledge have on profitability. Furthermore, the coefficients for the two sources of human capital, specifically service employees and professional employees, were not significant, suggesting that customer service firms that pursue a lowcost leader strategy do not realize additional profitability from greater investments in human capital. 
TABLE 1

Descriptive Statistics and Correlations for Firms with a Low-Cost Strategic Orientation

\begin{tabular}{|c|c|c|c|c|c|c|c|c|c|c|c|c|}
\hline Variable & $\mathbf{M}$ & SD & Min. & $\operatorname{Max}$ & 1 & 2 & 3 & 4 & 5 & 6 & 7 & 8 \\
\hline 1. Net income & 17.52 & 11.53 & 0.01 & 79.63 & 1.00 & & & & & & & \\
\hline 2. Cost of living & 101.20 & 7.59 & 89.40 & 121.40 & 0.42 & 1.00 & & & & & & \\
\hline 3. Market demand & 66.35 & 8.48 & 32.64 & 89.50 & 0.48 & 0.15 & 1.00 & & & & & \\
\hline 4. Physical/property asset & 87.54 & 50.69 & 2.36 & 368.79 & 0.34 & 0.21 & $0.09^{* * *}$ & 1.00 & & & & \\
\hline 5. Systems capital & 2.19 & 1.52 & 0.01 & 16.06 & 0.60 & 0.30 & 0.30 & 0.28 & 1.00 & & & \\
\hline 6. Customer capital & 3.07 & 1.54 & 0.01 & 9.67 & 0.53 & $0.08^{*}$ & 0.28 & 0.21 & 0.35 & 1.00 & & \\
\hline 7. Service employees & 10.84 & 5.32 & 1.89 & 31.73 & 0.39 & $0.13 * * *$ & $0.13^{* * *}$ & 0.26 & 0.33 & 0.50 & 1.00 & \\
\hline 8. Professional employees & 2.94 & 1.72 & 0.03 & 9.88 & 0.31 & 0.02 & $0.12^{* * *}$ & 0.27 & 0.18 & 0.49 & 0.82 & 1.00 \\
\hline
\end{tabular}

NOTE: $n=764$ observations.

${ }^{*} p<.05 .{ }^{* *} p<.01 .{ }^{* * *} p<.001$.

TABLE 2

Descriptive Statistics and Correlations for Firms with a Differentiation Strategic Orientation

\begin{tabular}{|c|c|c|c|c|c|c|c|c|c|c|c|c|}
\hline Variable & $\mathbf{M}$ & SD & Min. & $\operatorname{Max}$. & $I$ & 2 & 3 & 4 & 5 & 6 & 7 & 8 \\
\hline 1. Net income & 39.91 & 19.55 & 0.86 & 128.41 & 1.00 & & & & & & & \\
\hline 2. Cost of living & 104.93 & 7.45 & 90.60 & 124.40 & 0.38 & 1.00 & & & & & & \\
\hline 3. Market demand & 71.60 & 6.23 & 47.45 & 91.63 & 0.54 & 0.30 & 1.00 & & & & & \\
\hline 4. Physical/property asset & 194.72 & 126.71 & 3.52 & $1,016.69$ & 0.48 & 0.38 & 0.27 & 1.00 & & & & \\
\hline 5. Systems capital & 4.58 & 3.24 & 0.14 & 29.45 & 0.45 & 0.24 & 0.17 & 0.40 & 1.00 & & & \\
\hline 6. Customer capital & 4.26 & 2.99 & 0.01 & 18.90 & 0.23 & $0.10^{* * *}$ & 0.31 & 0.06 & -0.14 & 1.00 & & \\
\hline 7. Service employees & 22.37 & 10.55 & 7.35 & 87.58 & 0.54 & 0.33 & 0.13 & 0.41 & 0.56 & -0.15 & 1.00 & \\
\hline 8. Professional employees & 6.74 & 2.27 & 1.97 & 18.09 & 0.38 & 0.22 & 0.18 & 0.34 & 0.44 & -0.15 & 0.73 & 1.00 \\
\hline
\end{tabular}

NOTE: $n=819$ observations.

$* * * p<.001$.

In the second hypothesis, we predicted that for customer service firms that pursue a strategic orientation of differentiation, greater investments in all types of intellectual capital, including human capital, will result in higher levels of firm performance. As the significant positive coefficients reveal, this hypothesis was supported. Clearly, the strongest, positive predictor of profitability is investments in customer capital (coefficient $=1.037, p<.001$, vs. the systems coefficient of $0.393, p<.001$ ).

Additionally, greater investments in human capital also yield higher performance. Investments in service employees, versus those in professional employees, were found to be a stronger predictor of firm performance $(0.737, p<.001$, vs. $0.684, p<.001)$.

The chi-square values for the null model likelihood ratio test were $335.247(p<.001)$ and $539.140(p<.001)$ for the low-cost leadership and differentiation subsamples, respectively. The null model is the model with only the fixed effects and a diagonal homogeneous covariance matrix. The chisquare value is -2 times the log likelihood from the null model, minus -2 times the log likelihood from the fitted model. The significance of the likelihood ratio tests implies that for both subsamples, the estimated unstructured covariance matrix is preferred to the diagonal one of the OLS null model. 
Overall, the results suggest that investing in systems capital and customer capital has a positive and significant impact on customer service firm performance, while the return from investing in various sources of human capital depends on a firm's strategic orientation. The coefficient estimates reveal that for customer service firms that pursue a low- cost leadership strategic orientation, greater investments in human capital do not yield higher performance; however, customer service firms that pursue a differentiation strategy do reap the benefit of putting more money into both sources of human capital explored in this study. We now turn to a discussion of the implications of these findings for servicebased research.

\section{TABLE 3}

Results of Regression Analysis for Firm Performance in Hotels

\begin{tabular}{lcc}
\hline Variable & Low-Cost Leadership Orientation & Differentiation Strategic Orientation \\
\hline Intercept & $-46.814^{* * *}$ & $-110.040^{* * *}$ \\
Controls & & \\
Cost of living & $0.279^{* * *}$ & $0.345^{* *}$ \\
$\quad$ Market demand & $0.282^{* * *}$ & $1.098^{* * *}$ \\
Physical/property asset & -0.002 & -0.002 \\
Intellectual capital & & \\
Systems capital & $2.929^{* * *}$ & $0.393^{* *}$ \\
Customer capital & $2.446^{* * *}$ & $1.037^{* * *}$ \\
Human capital & & \\
Service employees & 0.085 & $0.737^{* * *}$ \\
Professional employees & 0.474 & $0.684^{*}$ \\
Number of observations & 764 & 819 \\
Degrees of freedom & 471 & 536 \\
Chi-square & $335.247^{* * *}$ & $539.140^{* * *}$ \\
\hline
\end{tabular}

a. Dummy-coded variables for the 55 management companies, 23 providers of brand, the four market segment variables, and the $\$$ trend variables (representing each year of analysis) were included as controls. We do not report the results here; however, they are available on request.

${ }^{*} p<.05 .{ }^{* *} p<.01 .{ }^{* * *} p<.001$.

\section{Discussion}

Fundamentally, customer service firms must make choices about investments in various types of intellectual capital that yield the highest return. Do firms put their money into operations knowledge acquired from outside sources, do they buy into a brand, or do they invest in their employees who offer professional expertise or service delivery skills? This study found that strategic orientation, in essence, provides the blueprint for customer service firms to make informed knowledge-based investments. Our results highlight how various types of intellectual capital are strategically important resources in differing contexts. Yet whether customer service firms choose to pursue a low-cost leader strategy or a differentiated strategy, they are more profitable when they make greater investments in customer 
capital and systems capital, both of which can be obtained from outside sources, such as the brands and management companies used by hotels in this study.

Indeed, the findings reveal that for customer service firms, purchasing access to customer capital is crucial to performance, especially for firms that pursue a differentiated strategy. This finding is consistent with previous research on brand and brand value, which examines the value associated with buying into a standardized product identity (i.e., Ambler et al. 2002; Hogan, Lemon, et al. 2002; Keller 1993; Koder 1991). Customer knowledge provides firms with costly advertising at a reduced price, an instant reputation via a brand logo, and efficient capacity management obtained through access to a global reservation system, participation in customer loyalty programs, and demand forecasting tools. Accessing this form of capital permits a single firm to benefit from an immediate image, an instant customer database, and direct access to distribution systems. It is also likely that investing in customer capital is essential to a firm's ability to attract its specific market niche; its associated brand reduces the risk for customers unfamiliar with the hotel, and through brand recognition, customers learn what to expect from the service product (Zeithaml 1988). And for differentiated hotels, greater expenditures on market-based assets result in higher performance, perhaps because of the benefits associated with a brand's cache and its related customer- relationship management programs.

\section{TABLE 3}

\section{Results of Regression Analysis for Firm Performance in Hotels}

\begin{tabular}{lcc}
\hline Variable & Low-Cost Leadership Orientation & Differentiation Strategic Orientation \\
\hline Intercept & $-46.814^{* * *}$ & $-110.040^{* * *}$ \\
Controls & & $0.345^{* *}$ \\
$\quad$ Cost of living & $0.279 * * *$ & $1.098^{* * *}$ \\
Market demand & $0.282^{* * *}$ & -0.002 \\
Physical/property asset & -0.002 & $0.393^{* *}$ \\
Intellectual capital & & $1.037^{* * *}$ \\
Systems capital & $2.929 * * *$ & \\
Customer capital & $2.446^{* * *}$ & $0.737^{* * *}$ \\
Human capital & & $0.684^{*}$ \\
Service employees & 0.085 & 819 \\
Professional employees & 0.474 & 536 \\
Number of observations & 764 & $539.140^{* * *}$ \\
Degrees of freedom & 471 & \\
Chi-square & $335.247^{* * *}$ & \\
\hline
\end{tabular}

a. Dummy-coded variables for the 55 management companies, 23 providers of brand, the four market segment variables, and the $\$$ trend variables (representing each year of analysis) were included as controls. We do not report the results here; however, they are available on request. ${ }^{*} p<.05 . * p<.01 .{ }^{* * *} p<.001$.

In addition, the results suggest that the more customer service firms spend on systems capital, through payment to outside management companies for access to their knowledge, the higher their profits. By applying the expertise honed by these outside specialists, firms can standardize their 
operations and improve their routines. This is especially relevant for low-cost leaders, who attain much higher performance from making substantial investments in the operational knowledge created by external vendors. The results reveal systems capital to be more critical than customer capital for lowcost hotels, highlighting the greater importance that acquiring best-practice operational information has over brand and other forms of market-based assets. For firms that differentiate, obtaining access to systems capital enables them to create a foundation from which they can customize their service product. For example, systems capital represents knowledge about how to streamline and integrate the series of service encounters that compose a hotel experience. Using this template, differentiating firms can personalize each encounter by having service providers from one encounter to the next share information about customer preferences.

What is interesting in this study's findings is the observation that not all customer service firms should "invest in people." Because the objective for low-cost leaders is to provide a basic product at a minimal cost, higher investments in systems capital and customer capital appear to be sufficient to meet this objective, without the need to incur additional investments in human capital. While a rudimentary staffing of employees is essential to operational functioning, additional investments in human capital do not enhance firm profitability in a statistically significant manner. This likely occurs because customers do not expect a personalized service experience or product but rather are looking for a more basic service product (i.e., a clean and simple hotel property). In short, enhanced performance may not always accrue to those who spend money on employees.

For truly customized service providers, however, higher investments in human capital are essential, as findings for differentiated hotels reveal. While firms that seek to differentiate their services also strongly benefit from investments in customer capital and, to a lesser degree, systems capital, findings suggest these firms will realize greater profitability through additional investments in employees. Likely, employees hold the unique, tacit knowledge about a firm's customers that enables the firm to offer specialized and enhanced services at a price premium. Offering these types of services would be essential to firms that wish to develop long-term relationships with customers that result in high repurchase behaviors.

However, what is also interesting to note is that for customer service firms that differentiate, in addition to service employees, investments in professional employees strongly affect performance. It may be the case that this employee group holds critical knowledge about how to implement the firm's overall positioning strategy to leverage the service concept. In other words, professional employees may be almost as crucial as service employees because they hold a sophisticated understanding of their 
customers' needs. In addition, they know how to organize the employees (and the services they deliver) so that the firm can meet these needs without having to incur additional investments in the operational knowledge provided by outside vendors. Our rationale is based on the argument that professionals are more likely than any other organizational group, including owners, to tacitly understand their firm's resources and competitive strength (Coff 2003; Makadok 2003). Thus, because they seek to provide a unique customer experience, differentiated firms can reap greater benefit from investments in internal resources, such as human capital, while similar investments in low-cost leader firms fail to deliver on needed efficiencies.

Customer service firms are often viewed as enterprises that minimize their investments in human capital because they employ low-skilled, living-wage workers. However, in these types of firms, a critical problem is retaining employees. Research continues to argue that low wages, rather than more sophisticated human resource practices such as career development, are the major causes of turnover (Enz 2004; Simons and Enz 1995). The findings suggest that some firms may benefit from reexamining this practice. Put simply, when differentiated hotels spend more on employees, by which we mean incurring higher wage and salary costs, they realize higher net operating income. Given this insight, decision makers in these strategically positioned firms may wish to give special attention to their compensation practices as a necessary starting point to protecting and leveraging human capital investments, especially at the service employee level.

Implications, Limitations, and Extensions

Our results have a number of implications. First and most important, the findings offer evidence that a customer service firm's strategic orientation should drive its intellectual capital investment decisions. As results suggest, depending on a firm's strategic orientation, increasing expenditures on various types of intellectual capital will differentially affect profitability. Thus, it is important for customer service firms to ensure that their investment in each of these types is consistent with their strategic orientation. The implication of these findings for decision makers in firms that pursue a lowcost leadership strategy is that they might wish to invest more in systems capital and customer capital to enhance long-term performance as substitutes for knowledge investments made within the firm. Spending more to affiliate with a high-quality management company and brand may be a wiser strategy than investing in service employees, even those with professional expertise. Firms that pursue a differentiation strategy would benefit from investments in all types of intellectual capital. Most important, decision makers in these types of customer service firms should avoid minimizing the short- 
term expense of service employees, because doing so may impair their firm's long-term performance. Specifically, trade-offs between investments in external systems capital and the internal expertise of professional employees are likely to be important strategic choices in these types of firms. In contrast, the results would suggest that low-cost providers should invest more in the operational knowledge that can be acquired from vendors and simultaneously minimize their spending on service and professional employees.

This study is one of the few that explores the way different types of intellectual capital are present in and influence firm profitability in customer service firms. It is also one of few studies that we know of that examines this issue using financial statements to construct key measures. We temper our findings, however, with a few important limitations. First, the study was conducted within one service sector context and is potentially limited in its generalizability. In addition, although a longer time frame would be desirable, we examine the impact of intellectual capital investments over a 4-year period. It is possible that some intellectual capital investments take more than a few years to produce a return. Also, because this study is based on financial measures and modeling, we know very little about the reasons why the phenomena we examine occur the way they do. It would have been useful to have additional data focused more specifically on the ways the hotels have chosen to invest in human capital. Measures of expenditures in training, for example, along with the educational levels of employees, would have been desirable supplemental indicators of investments in human capital. Yet we also recognize that salaries and wages represent a primary form of investment for customer service firms that employ lowskilled labor.

Despite these limitations, we believe our financial modeling approach enabled the use of concrete income statement metrics to examine the impact of intangible assets important to both researchers and business-level managers. In conceptually combining the production function framework from microeconomic theory with the resource-based view of the firm, as well as in incorporating the framework for competitive strategic orientations from the industrial economics tradition, we offer insight to work in the services marketing arena, which examines not only the midlevel impact of marketing initiatives (i.e., "did the initiative work?") but also the overall financial gains that accrue from knowledge-based investments (Srivastava et al. 1998).

Based on this contribution, there are a number of ways to extend the findings of this study. First, the resource- based literature clearly focuses on both resources and the firm-based capabilities they create (Grant 1996; Teece et al. 1997). We understand little about the ways these types of intellectual capital investments synergistically work together, as well as the conditions in which they represent 
tradeoff investments. While beyond the scope of this article, future studies might explore more deeply the intellectual capital investments that build firm-specific capabilities versus those that are derived from market transactions with external vendors. Second, future work should explore the impact of intellectual capital investments in other types of customer service firms, as well as in more professionally based service firms. Widening the study context to other sectors would enable researchers to examine industries that craft different mosaics of intellectual capital investments. So too, this research could be expanded into a longer time frame to determine whether there is a long-term relationship between current investments and future returns. Little is known about the role of time in exploring the impact of intellectual capital on performance. Given the high turnover of many service employees, time may be less important for investments in service workers but more critical to the returns from investments in professional employees. Finally, future studies framed with a survey-based methodology could help the field better understand how and why decision makers value intellectual capital investments and the various tools they use to evaluate their returns.

While there are natural extensions to our findings, we believe this study offers significant, standalone contributions. The results provide insight into the impact of the intellectual capital construct on customer service firms, breaking the contribution down into significant types of capital. Perhaps more importantly, we introduce the role of a firm's strategic orientation in influencing the differential impact intellectual capital investments have on performance. This important contextual feature has critical implications for a customer service firm's investment in its human capital. Overall, the results suggest that intellectual capital, and for some firms, human capital, represent investments that can provide customer service firms with enhanced firm performance and are knowledge assets that should be carefully protected.

\section{Conclusion}

Increasing competition in customer service firms points to the importance of superior intellectual capital as a major force in firm performance, a contention supported by the results of this study. While the focus of much current thinking has been on knowledge in professional service firms, the current study endeavored to explore the performance effects of intellectual capital in service firms with a large population of low-skilled employees. This study examined the use of intellectual capital in customer service firms that sought to be cost-efficient as well as those whose goals were to create customized service experiences. The findings reveal a path to financial success for customer service firms through investing in some types of intellectual capital. Our results have implications not only for 
those who study the impact of intellectual capital investments on performance but also for those who study the role of knowledge in customer service firms. In addition, the findings are useful for firms making strategic resource allocation decisions, especially when faced with the simultaneous challenge of delivering on a service concept, while hiring and retaining a labor pool in an industry notorious for its high turnover.

\section{References}

Ambler, Tim, C. B. Bhattacharya, Julie Edell, Kevin L. Keller, Katherine N. Lemon, and Vikas Mittal (2002), "Relating Brand and Customer Perspectives on Marketing Management," Journal of Service Research, 5, 13-25.

Amit, Raphael and Paul J. H. Shoemaker (1993), "Strategic Assets and Organizational Rent," Strategic Management Journal, 14, 33-46.

Anderson, Eugene W., Claes Fornell, and Roland T. Rust (1997), "Customer Satisfaction, Productivity and Profitability: Differences between Goods and Services," Marketing Science, 16, 129-145.

Andriessen, Daniel (2005), "Implementing the KPMG Value Explorer," Journal of Intellectual Capital, 6, 474-488.

Barney, Jay B. (1991), "Firm Resources and Sustained Competitive Advantage," Journal of Management, $22,99-120$.

Berndt, Ernst R. and Catharine J. Morrison (1995), "High-Tech Capital Formation and Economic Performance in U.S. Manufacturing Industries: An Exploratory Analysis," Journal of Econometrics, 65, 9-43.

Bitner, Mary J., Bernard H. Booms, and Mary S. Tetreault (1990), "The Service Encounter: Diagnosing Favorable and Unfavorable Incidents," Journal of Marketing, 54, 71-84.

Black, Janice A. and Kimberly B. Boal (1994), "Strategic Resources: Traits, Configurations and Paths to Sustainable Competitive Advantage," Strategic Management Journal, 15, 131-148.

Bonds, Nick and Jacques Fitz-enz (2002), “Intellectual Capital ROI: A Causal Map of Human Capital Antecedents and Consequences," Journal of Intellectual Capital, 3, 223-247.

—, William C. C. Keow, and Stanley Richardson (2000),

"Intellectual Capital and Business Performance in Malaysian Industries," Journal of Intellectual Capital, 1, 85-100. (1998), "Intellectual Capital: An Exploratory Study that

Develops Measures and Models," Management Decision, 36, 63-75. 
(1996), "There's a Price on Your Head: Managing Intellectual

Capital Strategically," Business Quarterly, Summer, 40-47.

Bowen, David E. and Benjamin Schneider (1988), "Services Marketing and Management: Implications for Organizational Behavior," in Research in Organizational Behavior, Vol. 10, B. M. Staw and T. G. Cmmings, eds. Greenwich, CT: JAI Press, 43-80.

and _- (1995), "Empowering Service Employees," Sloan Management Review, 36, 73-

84.

and Edward E. Lawler (1992), "The Empowerment of Service Workers: What, Why How and When," Sloan Management Review, 33, 31-39.

Brooking, Annie (1996), Intellectual Capital: Core Asset for the Third Millennium Enterprise. London: Thomson Publishing Inc.

Brynjolfsson, Erik and Larin M. Hitt (2003), “Computing Productivity: Firm-Level Evidence," The Review of Economics and Statistics, 85, 793-808.

Campbell-Hunt, Colin (2000), "What Have We Learned about Generic Competitive Strategy? A MetaAnalysis," Strategic Management Journal, 21, 127-154.

Carmeli, Abraham and Ashler Tishler (2004), "The Relationship between Intangible Organizational Elements and Organizational Performance," Strategic Management Journal, 25, 1257-1278.

Chan, Louis K. C., Josef Lakonishok, and Theodore Sougiannis (2001), "The Stock Market Valuation of Research and Development Expenditures," The Journal of Finance, 56, 2,431-2,456.

Coff, Russell W. (2003), "Bidding Wars over R\&D-Intensive Firms," Academy of Management Journal, 46, 74-85.

Constantin, James A. and Robert F. Lusch (1994), Understanding Resource Management. Oxford, OH: The Planning Forum.

Decarolis, Donna Marie and David L. Deeds (1999), "The Impact of Stocks and Flows of Organizational Knowledge on Firm Performance: An Empirical Investigation of the Biotechnology Industry," Strategic Management Journal, 20, 953-968.

Dzinkowski, Ramona (2000). "The Measurement and Management of Intellectual Capital: An Introduction," Management Accounting, 78, 32-36.

Edvinsson, Leif and Michael Malone (1997), Intellectual Capital: The Proven Way to Establish Your Company's Real Value by Measuring Its Hidden Brainpower. London: Biddles Ltd.

Engstrom, Truls, Petter Westnes, and Siren F. Westnes (2003) "Evaluating Intellectual Capital in the Hotel Industry," Journal of Intellectual Capital, 4, 287-303. 
Enz, Cathy A. (2004) "Issues of Concern for Restaurant Owners and Managers," Cornell H.R.A. Quarterly, 45, 315-327.

Ethiraj, Sendil K., Prashant Kale, M. S. Krishnan, and Jitendra V. Singh (2005), "Where Do Capabilities Come From and How Do They Matter? A Study in the Software Services Industry," Strategic Management Journal, 26, 25-45.

Flamholtz, Eric G., Maria L. Bullen, and Wei Hua (2002), “Human Resource Accounting: A Historical Perspective and Future Implications," Management Decision, 40, 947-954.

(1985), Human Resource Accounting: Advances in Concepts,

Methods and Applications. San Francisco: Jossey-Bass.

and John M. Lacey (1981), Personnel Management, Human

Capital Theory and Human Resource Accounting. Los Angeles: UCLA Institute of Industrial Relations.

Fulop, Christina and Jim Forward (1997), "Insights into Franchising: A Review of Empirical and

Theoretical Perspectives," The Services Industries Journal, 17, 603-625.

Gittell, Jody H. (2002), "Relationships between Service Providers and Their Impact on Customers,' ' Journal of Service Research, 4,299-311.

Goldstein, Susan M. and Peter T. Ward (2004), “Performance Effects on Physicians' Involvement in Hospital Strategic Decisions," Journal of Service Research, 6, 361-372.

Grant, Robert M. (2008), Contemporary Strategy Analysis, 6th edition. Malden, MA: Blackwell Publishing.

_ (1996), "Prospering in Dynamically-Competitive Environments:

Organizational Capability as Knowledge Integration," Organization Science, 4, 375-387.

Greene, William H. (2000), Econometric Analysis, 4th edition. Upper Saddle River, NJ: Prentice-Hall.

Gutek, Barbara A. (1995), The Dynamics of Service. San Francisco: Jossey-Bass.

Haas, Martine R. and Morton T. Hansen (2005), "When Using Knowledge Can Hurt Performance: The Value of Organizational Capabilities in a Management Consulting Company," Strategic Management Journal, 26, 1-24.

Hall, Brownyn (1993), "The Stock Market's Valuation of R\&D Investment during the 1980s," American Economic Review, 83, 259-264.

Hall, Richard (1993), “A Framework Linking Intangible Resources and Capabilities to Sustainable Competitive Advantage," Strategic Management Journal, 14, 607-618. (1992), "The Strategic Analysis of Intangible Resources," Strategic Management Journal, 13, 135-144. 
Hausman, James (1978), "Specification Tests in Econometric," Econometrica, 46, 69-85.

Hitt, Michael A., Leonard Bierman, Katsuhiko Shimizu, and Rahul Kochhar (2001), “Direct and

Moderating Effects of Human Capital on Strategy and Performance in Professional Service Firms:

A Resource-Based Perspective," Academy of Management Journal, 4, 13-26.

Hogan, John E., Donald R. Lehmann, Maria Merino, Rajendra K. Srivastava, Jacquelyn S. Thomas, and Peter C. Verhoef (2002), “Linking Customer Assets to Financial Performance," Journal of Service Research, 5, 26-38.

, Katherine N. Lemon, and Roland T. Rust (2002), “Customer Equity Management: Charting New Directions for the Future of Marketing," Journal of Service Research, 5, 4-12.

Inma, Chutarat (2005), "Purposeful Franchising: Re-Thinking of the Franchising Roundtable," Singapore Management Review, 27, 27-48.

Kamath, G. Breathe (2007), "The Intellectual Capital Performance of Indian Banking Sector," Journal of Intellectual Capital, 8, 96-123.

Keller, Kevin L. (1993), “Conceptualizing, Measuring and Managing Customer-Based Brand Equity," Journal of Marketing, 57, 1-22.

King, Adelaide Wilcox and Carl P. Zeithaml (2003), “Measuring Organizational Knowledge: A Conceptual and Methodological Framework," Strategic Management Journal, 24, 763-772.

Kothari, S. P., Ted E. Laguerre, and Andrew J. Leone (2002), “Capitalization Versus Expensing: Evidence on the Uncertainty of Future Earnings from Capital Expenditures Versus R\&D Outlays," Review of Accounting Studies, 7, 355-382.

Kotler, Phillip H. (1991), Marketing Management: Analysis, Planning and Control. Englewood Cliffs, NJ: Prentice-Hall.

Lane, Peter J. and Michael Lubatkin (1998), "Relative Absorptive Capacity and Interorganizational Learning," Strategic Management Journal, 19, 461-477.

Lane, Vicki and Robert Jacobson (1995), "Stock Market Reactions to Brand Extension Announcements: The Effects of Brand Attitude and Familiarity," Journal of Marketing, 59, 63-77.

Lepak, David P. and Scott A. Snell (2002), "Examining the Human Resource Architecture: The Relationships among Human Capital, Employment and Human Resource Configurations," Journal of Management, 28, 517-543. and - (1999), "The Human Resource Architecture: Toward a Theory of Human Capital Allocation and Development," Academy of Management Review, 24, 31-48. 
Lev, Baruch and Theodore Sougiannis (1996), "The Capitalization, Amortization, and Value-Relevance of R\&D," Journal of Accounting and Economics, 21, 107-138.

Lippman, Steven A. and Richard P. Rumelt (2003), "The Payments Perspective: Micro-Foundations of Resource Analysis." Strategic Management Journal, 24, 903-927.

Mahoney, Joseph T. and J. Rajendran Pandian (1992), "The Resource- Based View within the Conversation of Strategic Management," Strategic Management Journal, 13, 363-380.

Mairesse, Jacques and Mohamed Sassenou (1991), "R\&D and Productivity: A Survey of Econometric Studies at the Firm Level," NBER Working Paper No. 3666.

Makadok, Richard (2003), “Doing the Right Thing and Knowing the Right Thing to Do: Why the Whole Is Greater than the Sum of the Parts," Strategic Management Journal, 24, 1043-1055.

McEvily, Susan K. and Bala Chakravarthy (2002), "The Persistence of Knowledge-Based Advantage: An Empirical Test for Product Performance and Technological Knowledge," Strategic Management Journal, 23, 285-305.

Mills, Peter K. and Gerardo R. Ungson (2001), "Internal Market Structures," Journal of Service Research, 3, 252-264.

Mowery, David C., Joanne E. Oxley, and Brian S. Silverman (1996), "Strategic Alliances and Interfirm Knowledge Transfer," Strategic Management Journal, 17, 77-91.

Nachum, Lilach (1999), "The Productivity of Intangible Factors of Production: Some Measurement Issues Applied to Swedish Management Consulting Firms," Journal of Service Research, 2,123-137.

Namasivayam, Karthik and Basak Denizci (2006), "Human Capital in Service Organizations: Identifying Value Drivers," Journal of Intellectual Capital, 1, 381-393.

Ng, Artie W. (2006), "Reporting Intellectual Capital Flow in Technology-Based Companies," Journal of Intellectual Capital, 7, 492-510.

Oliva, Rogelio and John D. Sterman (2001), “Cutting Comers and Working Overtime: Quality Erosion in the Service Industry," Management Science, 47, 892-914.

Oliver, Christine (1997), "Sustainable Competitive Advantage: Combining Institutional and ResourceBased Views," Strategic Management Journal, 18, 697-713.

Parasuraman, A., Valerie A. Zeithaml and Leonard L. Berry (1988), "SERVQUAL: A Multiple-Item Scale for Measuring Consumer Perceptions of Service Quality," Journal of Retailing, 64, 12-40.

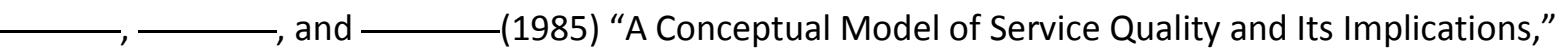
Journal of Marketing, 49, 41-50.

Penrose, Edith Tilton (1959), The Theory of the Growth of the Firm. New York: Wiley. 
Peteraf, Margaret A. (1993), "The Cornerstones of Competitive Advantage: A Resource-Based View," Strategic Management Journal, 14, 179-181.

Petrash, Gordon (1996), “Dow's Journey to a Knowledge Value Management Culture," European Management Journal, 4, 365-373.

Porter, Michael E. (1985), Competitive Advantage: Creating and Sustaining Superior Performance. New York: Free Press.

Rafferty, Adrian (1995), "Bayesian Model Selection in Social Research," in Sociological Methodology, P. Marsden, ed. Washington, DC: American Sociological Association, 111-163.

Reichheld, Frederick F. (1996), The Loyalty Effect: The Hidden Force Behind Growth, Profits and Lasting Value. Boston: Harvard Business School Press.

Reinartz, Wener and V. Kumar (2002), "The Mismanagement of Customer Loyalty," Harvard Business Review, 80, 86-94. and - (2000), "On the Profitability of Long-Life Customers in a Noncontractual Setting: An Empirical Investigation and Implications for Marketing," Journal of Marketing, 64, 17-35. Riahi-Belkaoui, Ahmed (2003), "Intellectual Capital and Firm Performance of U.S. Multinational Firms," Journal of Intellectual Capital, 4, 215-226.

Roos, Johan, Goran Roos, Nicola C. Dragonetti, and Leif Edvinsson (1997), Intellectual Capital: Navigating the New Business Landscape. London: Macmillan Press.

Rumelt, Richard P. (1984), "Toward a Strategic Theory of the Firm," in Competitive Strategic Management, R. Lamb, ed. Englewood CUffs, NJ: Prentice-Hall, 520-528.

Russo, Michael V. and Paul A. Fouts (1997), "A Resource-Based Perspective on Corporate Environmental Performance and Profitability," Academy of Management Journal, 40, 534-559.

Rust, Roland T. and Anthony Zahorik (1993), “Customer Satisfaction, Customer Retention and Market Share," Journal of Retailing, 69, 193-215.

Sackmann, Sonja, Eric G. Flamholtz, and Maria Bullen (1989), "Human Resource Accounting: A State of the Art Review," Journal of Accounting Literature, 8, 235-264.

Schmidgall, Raymond S. (1999), Hospitality Industry Financial Accounting. Educational Institute. Lansing, MI: American Hotel \& Motel Association.

Seetharaman, A., Hadi H. B. Z. Sooria, and A. S. Saravanan (2002), "Intellectual Capital Accounting and Reporting in the Knowledge Economy," Journal of Intellectual Capital, 3, 128-148.

Shane, Scott (1998), "Making New Franchise Systems Work," Strategic Management Journal, 19, 697707. 
Sherer, Peter D. (1995), "Leveraging Human Assets in Law Firms: Human Capital Structures and Organizational Capabilities," Industrial and Labor Relations Review, 48, 671-691.

Siehl, Caren, David E. Bowen, and Christine M. Pearson (1992), "Service Encounters as Rites of Integration: An Information Processing Model," Organization Science, 3, 537-555.

Simons, Tony and Cathy A. Enz (1995), "Motivating Hotel Employees: Beyond the Carrot and the Stick," Cornell H.RA. Quarterly, 36, 20-27.

Smith, Gordon V. and Russell L. Parr (2000), Valuation of Intellectual Property and Intangible Assets. New York: John Wiley \& Sons.

Spender, J. C. and Robert Grant (1996), "Knowledge and the Firm: Overview," Strategic Management Journal, Winter Special Issues, 17, 27-43.

Srivastava, Rajendra K., Tasaddug A. Shervani, and Liam Fahey (1999), “Marketing, Business Process, and Shareholder Value: An Organizationally Embedded View of Marketing Activities and the Discipline of Marketing," Journal of Marketing, 63, 168-179.

— Analysis," Journal of Marketing, 62, 2-18.

Stewart, Thomas A. (1997), Intellectual Capital: The Wealth of New Organizations. London: Nicholas Brealey Publishing.

Sveiby, Karl E. (1997), The New Organizational Wealth: Managing and Measuring Knowledge-Based Assets. San Francisco: Berrett- Koehler Publishers Inc.

Swart, Juani (2006), "Intellectual Capital: Disentangling an Enigmatic Concept," Journal of Intellectual Capital, 7, 136-159.

Teece, David J. (2000), Managing Intellectual Capital. Oxford, UK: Oxford University Press.

—, Gary Pisano, and Amy Shuen (1997), “Dynamic Capabilities in Strategic Management," Strategic Management Journal, 18, 509-534.

Vargo, Stephen, L. and Robert F. Lusch (2004), "Evolving to a New Dominant Logic for Marketing" Journal of Marketing, 68, 1-17.

Vavra, T. G. (1992), After marketing: How to Keep Customers for Life through Relationship Marketing. Homewood, IL: Irwin.

Wang, Wannchemg (2005), "An Evaluation of the Balanced Scorecard in Equity Valuation," Journal of Intellectual Capital, 6, 206-221.

Washburn, Judith H., Brian D. Till, and Randi Priluck (2004), "Brand Alliance and Customer-Based BrandEquity Effects," Psychology \& Marketing, 21, 487-508. 
Weigelt, Keith and Colin Camerer (1988), "Reputation and Corporate Strategy: A Review of Recent Theory and Applications," Strategic Management Journal, 9, 443-454.

Wernerfelt, Birger (1984), “A Resource-Based View of the Firm," Strategic Management Journal, 5, 171180.

White, Halbert (1980), “A Heteroskedasticity-Consistent Covariance Matrix Estimator and a Direct Test for Heteroskedasticity," Econometrica, 48, 817-838.

Wiklund, Johan and Dean Shepherd (2003), "Knowledge-Based Resources, Entrepreneurial Orientation and the Performance of Small and Medium-Sized Businesses," Strategic Management Journal, 24, 1307-1314.

Zeithaml, Valerie A., Ruth N. Bolton, John Deighton, Timothy L. Keiningham, Katherine N. Lemon, and J. Andrew Peterson (2006), “Forward-Looking Focus: Can Firms Have Adaptive Foresight?” Journal of Service Research, 9, 168-183.

(2000), "Service Quality, Profitability and the Economic Worth of Customers: What We Need to Know and What We Need to Learn," Academy of Marketing Science, 28, 67-85.

Zeithaml, Valerie A., Leonard L. Berry, and A. Parasuraman (1996), "The Behavioral Consequences of Service Quality" Journal of Marketing, 60, 31-46.

— - , and _ (1993), "The Nature and Determinants of Customer Expectations of Service," Journal of the Academy of Marketing Science, 21, 1-12.

- (1988), "Consumer Perceptions of Price, Quality and Value: A Means-End Model and Synthesis of the Evidence," Journal of Marketing, 52, 2-22.

, A. Parasuraman, and Leonard L. Berry (1985), "Problems and Strategies in Services Marketing," Journal of Marketing, 49, 33-46.

\footnotetext{
${ }^{1}$ We use the terms performance and profitability interchangeably. In addition, the terms strategy and strategic orientation are also used synonymously, although the focus is on the popular generic types conceptualized by Porter (1985).

${ }^{2}$ The business-level or individual hotel property, not the hotel chain corporation, is the unit of analysis for this investigation.
} 